\title{
The Role of Customer Knowledge Management Process in Service Recovery Performance: An Applied Study to the Egyptian National Railways
}

\author{
Nehal El-Helaly, \\ Mansoura University, Egypt
}

Ahmed Ebeid,

Mansoura University, Egypt

\author{
Azza El-Menbawe, \\ Mansoura University, Egypt
}

\begin{abstract}
Customer knowledge represents an important organisational asset that organisations would utilize and manage to gain a competitive advantage. The purpose of this study is to develop and test a model to explain the role of customer knowledge management in service recovery performance; through examining the impact of Customer Knowledge Management (CKM) process on Service Recovery Performance (SRP), based on the perspective of the Egyptian National Railways' employees. It also attempts to measure how employees and customers evaluate the Egyptian National Railways' actual performance of service recovery.
\end{abstract}

This paper has demonstrated the value of managing customer knowledge effectively in order to achieve a higher performance on service recovery. The empirical results indicated that organisations need to capture, share, acquire, and apply customer knowledge successfully in order to improve their service recovery performance. The results also demonstrated that employees evaluate their performance regarding the service recovery more positively than what customers do.

Paper type: Research paper

Keywords: Customer Knowledge, Customer Knowledge Management, Service Failure, Service Recovery, Service Recovery Performance 


\section{Introduction}

Knowledge workers and service economy have become global megatrends since the beginning of twenty-first century. Managing customer knowledge becomes increasingly important in the rise of the service economy. Customer knowledge represents an important organisational asset that organisations would utilize and manage to gain competitive advantage (El-Helaly et al., 2013). Customer knowledge is useful to an organisation in terms of generating aggregate markets knowledge, providing tailored solutions to meet customers' changing demands, and support long-term customer relationships (Salojarvi, 2009; Sofianti et al., 2009; Williams, 2014). Organisations could manage $\mathrm{CK}$ in order to improve innovation, support research and development, and facilitate organisation's sense of emerging market opportunities (Sofianti et al., 2009).

CKM is considered as a continuous strategic process by which organisations enable their customers to move from being passive buyers and information sources, to become empowered knowledge partners (Chen and Huang, 2011). CKM also represents an organisational approach that organisations utilize to support the role of their customers as value co-creators within the organisation (Belkahla and Triki, 2011).

On the other hand, service involves the exchange of time, efforts, and money between an organisation and its customers; both of them have expectations about the quality of service (Najjar, Smithy and Kettingerz, 2010). The quality of service depends on various factors, such as: customer's expectations, and the attitude and behaviour of front-line employees. In addition, many services are produced and consumed at the same time leaving no room for inspecting it before delivered to customers. This implies that it is virtually impossible for the organisations to deliver error-free services even if they are fully committed to provide high-quality services for their customers (Río-Lanza et al., 2009). Poor service delivery not only harms the long-term profitability of a firm but also threaten the sustainability of the firm.

Service Recovery (SR) refers to taking the appropriate action that would turn the mistake or failure in service delivery into a positive and favourable situation (Gustafsson, 2009). It typically comprises action and process an organisation attempt to rectify the error (Río-Lanza et al., 2009). Common approaches to SR include the following: communicating with unsatisfied customers, apologising to customer for the inconvenient situation, providing customer with a timely feedback, empowering employees to act and make decisions regarding the problem at hand, and ensuring that employees are professional and well-dressed when dealing with unsatisfied customers (Boshoff, 2005). A successful implementation of SR allows service-providers to regain customers trust, minimise further potential losses and even increase customer loyalty (Boshoff, 2005; Liao, 2007; Wang et al., 2011).

Based on literature review, it is a widely held view that customer knowledge is recognised as a vital organisational resource that organisations could manage to improve the processes of customer service and retention. However, limited understanding of its impact on service recovery performance is known. Therefore, the

International Journal of Management and Applied Research, 2015, Vol. 2, No. 1 
current research attempts to fill this research gap through empirically investigating the impact of customer knowledge management process on service recovery performance.

The remainder of paper is organized as follows: first, the literature review is discussed. Next, the research model and hypotheses is constructed. After that, the research method and the empirical study results are outlined. Finally, research implications, limitations and recommendations are presented.

\section{Literature Review}

Many scholars started to realise the importance of managing knowledge and that knowledge could came from diverse sources including customers, employees, partners, products, processes, competitors, and experiences (García-Murillo and Annabi, 2002). Equally, many organisations have indeed recognised the value of sharing and managing knowledge from different sources but the practices of disseminating knowledge typically take place within the organisations. In line with García-Murillo and Annabi, (2002), this paper argues that, by gaining customer knowledge, companies can capture richer content of customer preference and make improvements accordingly.

\subsection{Customer Knowledge (CK)}

Customer knowledge is widely accepted as a dynamic combination of experience, values, contextual information, and expert insight which is needed, created and observed during the transaction and exchange between customers and the organisation and that provides a framework for evaluating and incorporating new experiences and information (Roy and Stavropoulos, 2007; Jochems, 2013).

Previous studies identified three types of customer knowledge. First, knowledge about customer represents the knowledge type that organisation attains to know its target customers better (Wu et al., 2013). Organisations require this knowledge to identify their customers' requirements; so as to address them in a personalized way (Williams, 2014). Second, knowledge for customer refers to knowledge type provided by organisation to its target customers (Parirokh et al., 2009). It could flow from the organisation to its customers - regarding its products, markets and suppliers - with the aim of supporting them (Salomann et al., 2005; Williams, 2014). And last but not least, knowledge from customer is the knowledge type that resides within customers' minds and that organisation attains to support its products (Wu et al., 2013). This type of knowledge generated and captured through customer interactions with the organisation (Daghfous et al., 2008; Garcia-Murillo and Annabi, 2002; Williams, 2014).

\subsection{Customer Knowledge Management (CKM) Process}

CKM is defined as "the process of capturing, sharing, acquiring and applying all types of customer knowledge in order to create value for both customers and the organisation" (El-Helaly, 2013: 32).

The process of CKM as introduced by Garcia-Murillo and Annabi (2002) consists of three stages, which includes; knowledge revealing, knowledge sorting, and knowledge levelling. Essentially, these three steps focus on a continuous process of satisfying

International Journal of Management and Applied Research, 2015, Vol. 2, No. 1 
information needs for both customers and companies. On one hand, there is a need for customers to understand product or service offerings; on the other hand, there is a need for better understanding of the customer preferences. The information seeking behaviours from both sides play an imperative role here. In a similar vein, $\mathrm{Su}$ et al. (2006) presented an E-CKM model which consists of four stages: product features/benefit identification, customers' needs categorization, market segmenting for converting tacit customer knowledge into codified knowledge, and customers' needs pattern extraction. While the CKM as proposed by Garcia-Murillo and Annabi (2002) derives from social interactions among customers and employees, the E-CKM comes from the use of web-based survey and data mining techniques.

Dalkir (2005) presented an integrated CKM process model including three stages: customer knowledge capture, customer knowledge sharing, and customer knowledge acquisition and application. In the transition from customer knowledge capture stage to the stage of customer knowledge sharing, knowledge content is assessed. In order to understand and utilize this knowledge it has to be contextualized to move into knowledge acquisition and application stage. This stage then feeds back into the first one in order to update the knowledge content. The integrated CKM process model is outlined in Figure 1.

Figure 1: Integrated CKM Process Model

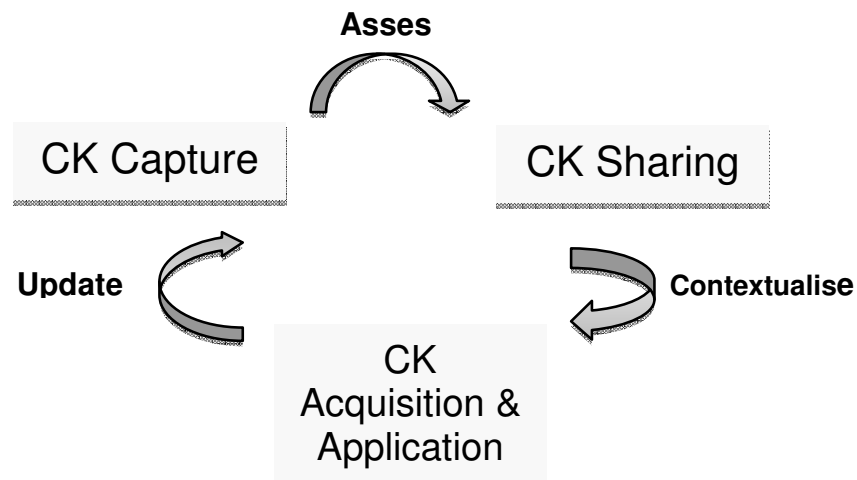

Source: Dalkir (2005: 43)

According to this model, organisation captures customer knowledge either directly or indirectly. This customer knowledge is then accessed and shared by the employees in order to be contextualized; so that it could be used for enhancing and updating existing services; and developing new and innovative services. Explanations on each of the three major stages of the integrated CKM process model are discussed below.

\subsubsection{Customer Knowledge Capture}

Knowledge capture refers to the identifying and gathering existing knowledge both internally within the organisation, and/or externally from its environment. This stage is related to two types of customer knowledge which are knowledge about customer and

International Journal of Management and Applied Research, 2015, Vol. 2, No. 1 
knowledge from customer. These types of customer knowledge are initially captured either directly or indirectly through data mining or knowledge discovery.

\subsubsection{Customer Knowledge Sharing}

During this stage customer knowledge is integrated, disseminated, and shared among employees and other decision makers within the organisation. The organisation distributes knowledge among its employees and encourages them to share their knowledge.

\subsubsection{Customer Knowledge Acquisition and Application}

During this stage employees understand customer knowledge (i.e. knowledge acquisition); and apply it in supporting and modifying existing services or in developing new innovative services. Organisations are able to search their customer knowledge repositories for specific information related to the problem they are solving in order to provide better service and build sustainable customer relationships.

\subsection{Service Failure (SF)}

It is nearly impossible to eliminate all service failures due to the intangibility and inseparability characteristics of service (Wang et al., 2011). Service failure occurs when a customer is dissatisfied or feels negatively about the service (Patterson, Cowley and Prasongsukarn, 2006) or when the customers' perceived service quality falls below their expectations (Akbar et al., 2010). However, the core service failure do not directly leads to brand switch; rather, the main factor that caused an unhappy customer switched to another service provider is the failure to handle customer complaints and the subsequent customer dissatisfaction (Keaveney, 1995). An effective performance management system must therefore include assessment of service recovery strategies especially for service industry.

\subsection{Service Recovery (SR)}

Empirical studies indicated that satisfactory service recovery not only eliminates potential negative word-of-mouth intention (Casidy and Shin, 2015) but also improves overall satisfaction (Boshoff, 2005; Gustafsson, 2009; Río-Lanza et al., 2009) and contributes to customer loyalty (Boshoff, 2005; Liao, 2007; Wang et al., 2011). Service recovery could be defined as the strategy undertaken by an organisation to identify and correct the service failure in order to retain customer satisfaction and loyalty (El-Helaly, 2013). It refers to taking the appropriate action that would turn the mistake or failure in service delivery into a positive and profitable situation.

The success of the organisation in implementing an effective service recovery would increase the level of customer confidence; and as a result, those satisfied customers would spread positive word-of-mouth about the organisation (Gustafsson, 2009). On the contrary, poor service recovery could lead to customer anger (Joireman et al. 2013) and negative word-of-mouth (Casidy and Shin, 2015).

International Journal of Management and Applied Research, 2015, Vol. 2, No. 1 


\subsection{Service Recovery Performance (SRP)}

Service recovery performance is considered as an important strategic issue in the literature of services marketing (Rod, Ashill and Carruthers, 2008). Service recovery performance is defined as "the behaviours in which customer service employees who directly handle customer complaints engage to recover customer satisfaction and loyalty after service failures" (Liao, 2007, p. 476(. It is concerned with the actions taken by employees to implement the organisational service recovery strategy (El-Helaly, 2013). Low level of SRP leads to undesired outcomes for any organisation; so that organisations need to understand the factors that affect the organisational efforts in response to SF in order to minimize its negative effects on organisational effectiveness (Rod, Ashill and Carruthers, 2008).

Effective service recovery is not just an after-thought, but is rather an intentionally designed part of a service delivery system that has been planned into the service design in support of the service concept (Chaharsoughi, 2008). As a result, the goal of service recovery is not only to correct specific instances of service failure, but also to improve the service delivery system so as to precluding any future instances of failure; enhancing customers' overall perceptions of service quality; and supporting long-term customer relationships (Vaerenbergh, Vermeir and Lariviere, 2010).

Effective service recovery can be achieved through communicating with the dissatisfied customer, being compassionate, providing feedback, providing an explanation for the service failure, empowering employees to communicate suitably with customers, and ensuring that employees dealing with customers are well-dressed (Boshoff, 2005). Moreover, Gu and Ye (2010) argued that service organisations can offer a variety of compensations for service recovery, ranging from monetary compensation such as discount for future services to social compensation such as an apology.

To evaluate the effectiveness of service recovery, a number of researchers (e.g. Boshoff, 1999; Boshoff, 2005; Najjar et al., 2010) focused on measuring customers' satisfaction with service recovery, while some scholars (e.g. Boshoff and Allen, 2000; Liao, 2007; Rod, Ashill and Carruthers, 2008) measured the performance of service recovery based on the self-reflection of employees.

Najjar et al. (2010) presented the following service recovery dimensions: apology, explanation, responsiveness, recovery speed, recovery effort, and recovery level. While the first three elements are concerned with empathy, the last three components are more related to efficiency. The work of Najjar et al. (2010) is in line with the works of Boshoff $(1999 ;$ 2005) which highlights the need of showing compassion and immediacy. Boshoff (1999) developed a six factor structure "RECOVSAT" an instrument to measure customer satisfaction with the efforts of service recovery: communication, employee empowerment, feedback, atonement, explanation, and tangibles. In 2005, Boshoff conducted an empirical assessment of the psychometric properties of "RECOVSAT" and confirmed that "RECOVSAT" is a useful processbased metric to measure the functional quality of service recovery.

International Journal of Management and Applied Research, 2015, Vol. 2, No. 1 
In a similar vein, scholars such as Rod et al. (2008) and Boshoff and Allen (2000) measured Service Recovery Performance (SRP) using the following five statements: (1) considering all the things I do, I handle dissatisfied customers quite well, (2) I don't mind dealing with complaining customers, (3) no customer I deal with leaves with problems unresolved, (4) satisfying complaining customers is a great thrill to me, and (5) complaining customers I have dealt with in the past are among today's most loyal customers.

Liao (2007) presented a five-dimension model to measure Service Recovery Performance (SRP), these dimensions are: making an apology, problem solving, being courteous, providing an explanation, and prompt handling, as discussed below.

\subsubsection{Making an apology}

Customer complaints indicate that he identified the problem and blamed the organisation. Thus, denial of responsibility will be poorly received. By apologising to customers, the organisation and its employees accept the responsibility for service failure, and regret for negative events. Research shows that apology is associated with higher customer satisfaction following a service failure.

\subsubsection{Problem solving}

Beyond receiving an apology, customers typically expect the mistake to be corrected and the problem to be resolved in. If service employees fail to solve the problem, customers will feel that they have not received the outcomes they expect and deserve. At this point, the service employees' ability to solve the service problems can influence customer satisfaction and service quality evaluations.

\subsubsection{Being courteous}

It is an important dimension of SRP that consists of customer service employees' behaviours that demonstrate politeness, respect, friendliness, and patience when interacting with customers. It is an important dimension of SRP that may influence customer satisfaction with service recovery through its impact on customer-perceived justice.

\subsubsection{Providing an explanation}

It refers to providing customer with a clear and reasonable cause for service failure. Customers view the explanation as an important piece of information, a valuable outcome, and a means to understand and control their service environment. In addition, open communication may alleviate customers' bad feelings about the service failure.

\subsubsection{Prompt handling}

It refers to service employees' quick response to a customer complaint. Customers may view this prompt response as a valuable outcome and an appropriate way for the service employee to communicate and interact with customers. 


\section{Problem Statement}

Service recovery represents a "second chance" (Joireman et al., 2013) for organisations to rectify mistakes and redress service failures effectively. Moreover, Rod et al. (2008) suggested that satisfying unhappy customer due to service failure is more important than pre-failure satisfaction. This implies that customers who encountered service failure and their issues are resolved are more likely to revisit the store and make another purchase than those who did not experience any service failure. However, repeated service failures may not be able to recover to a customer's full satisfaction (Boateng and Agyemang, 2015) despite the service recovery strategy is appropriate and timely. Tax and Brown (1998) stated that most customers are dissatisfied regarding the service recovery performance due to ignorance of customer needs and expectations in their attempt to redress the failure.

A pilot study was conducted based on structured personal interviews with railway stations' managers and a convenience sample of 50 train passengers (El-Helaly, 2013). This pilot study concluded that the service provided by the ENR has encountered some problems and failures, and customers are not satisfied with its SRP. This could be attributed to the fact that ENR do not take customer knowledge (e.g. customer's needs, and expectations) when implementing its service recovery process. In short, there is a discrepancy between the ENR's service recovery activities and its customers' desires and expectations of the acceptable level of the service recovery performance.

\section{Research Model and Hypotheses}

\subsection{Conceptual Research Model}

This research developed a simple model (figure 2) to examine the impact of CKM process on SRP that integrated the process of CKM provided Dalkir (2005) and the five-dimension model of SRP presented by Liao (2007).

Figure 2: Conceptual Research Model

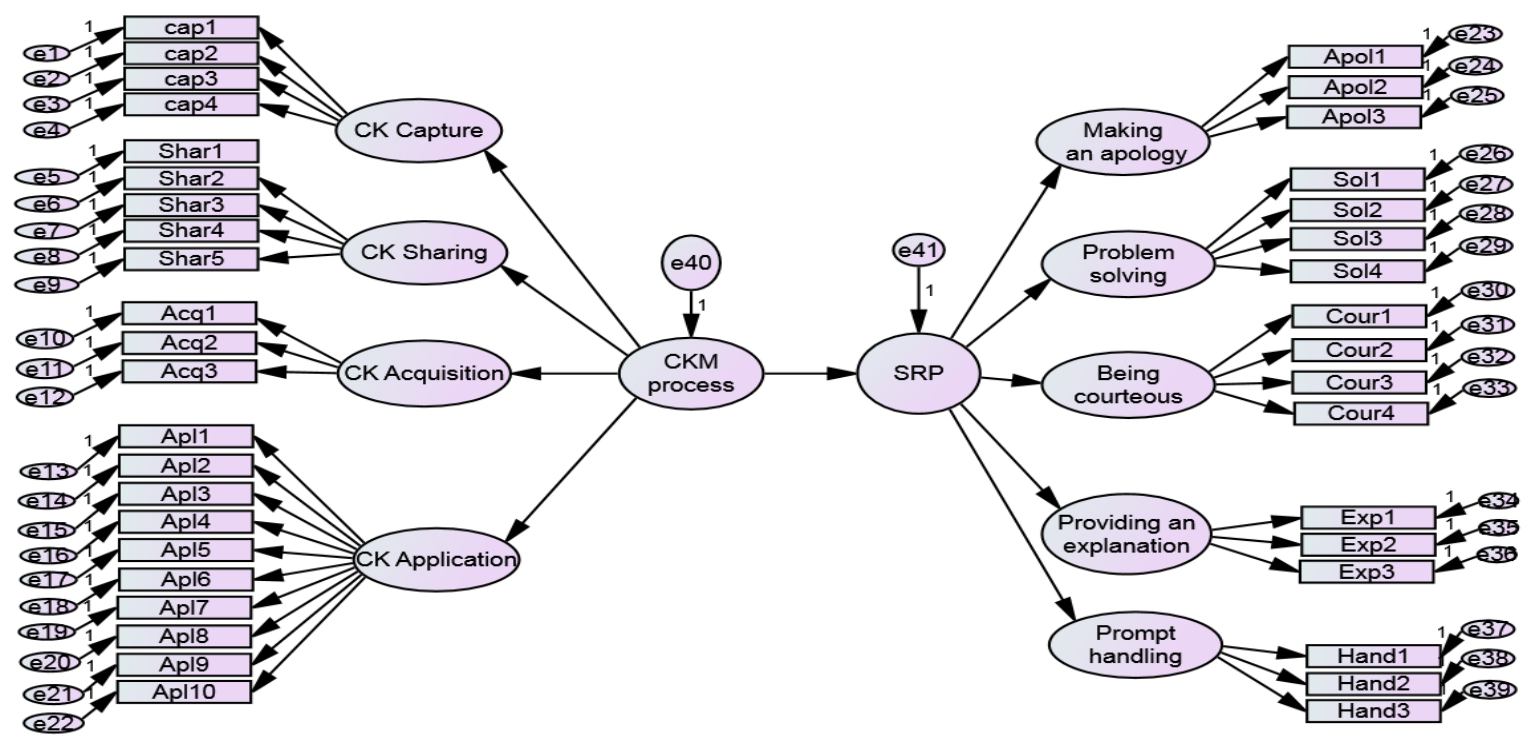

International Journal of Management and Applied Research, 2015, Vol. 2, No. 1 


\subsection{Research Hypotheses}

Organisations need to manage their customer knowledge; in order to know what customers need and expect from them, in terms of the service failure. Then, they would compare such customer knowledge with actual service recovery performance to determine whether it is effective or not (Boshoff, 1999). Therefore, the current research investigates the role of CKM process in SRP, through testing the following hypothesis:

H1. Customer knowledge management process has a significant impact on service recovery performance.

Guo and Niu (2007) indicated that organisations have to capture and share customer knowledge effectively; and when a service failure occurs, they would apply customer knowledge to implement service recovery successfully; so that, the current research tries to identify whether each stage of CKM process (i.e. CK capture, CK sharing, CK acquisition, and CK application) have a significant impact on SRP; through testing the following hypothesis:

H2. Customer knowledge management stages (i.e. CK capture, $C K$ sharing, $C K$ acquisition, and $C K$ application) have a significant impact on service recovery performance.

Bitner et al. (1994) mentioned that it is important to evaluate the service performance from both service provider and customer perspectives; as the service encounter involves those two parties. Therefore, the current research aims at evaluating the service recovery performance not only from customers' point of view, but also from employees' point of view, through testing the following hypothesis:

H3. There are no significant differences between the Egyptian National Railways' employees and its customers in terms of their evaluation to service recovery performance.

\section{Research Methods}

\subsection{Population and Sample}

The current research has two populations: (1) Population of the ENR's employees that includes all front-line employees (i.e. employees who deal directly with train passengers). (2) Population of the ENR's Customers consists of all the train passengers. A census technique was used to collect primary data from the employees' population, whereas an intercept sample consisting of 384 passengers was taken from the customers' population.

\subsection{Questionnaire Design}

The questionnaire provided to ENR's employees consists of two parts containing 39 statements (see Table 1). The first part was designed to examine CKM process and it contains four constructs: CK capture reflected by statements (1-4), CK sharing reflected by statements (5-9), CK acquisition reflected by statements (10-12), and CK application

International Journal of Management and Applied Research, 2015, Vol. 2, No. 1 
reflected by statements (13-22). The second part was designed to identify SRP and it includes five constructs: making an apology reflected by statements (23-25), problem solving reflected by statements (26-29), being courteous reflected by statements (3033), providing an explanation reflected by statements (34-36), and prompt handling reflected by statements (37-39). The questionnaire provided to ENR's customers consists of the same 17 statements of SRP contained in the second part of employees' questionnaire; in order to facilitate the comparing process between the two populations' opinions regarding the SRP of the ENR. All scales items were integrated from various previous studies. For measuring all variables, a five-point Likert scale is used ranging from strongly disagree (1) to strongly agree (5).

\subsection{Data Collection}

Data collection was carried out by two structured questionnaires administered through personal interviews. First questionnaire was issued in Arabic to the front-line employees of the ENR to identify their opinions regarding both of customer knowledge management process and service recovery performance. Second questionnaire was also provided in Arabic to the customers of the ENR to investigate their opinions regarding the ENR's service recovery performance. The completed employees' questionnaires were 203 with responding rate of $85.7 \%$ whereas customers' completed questionnaires were 333 with responding rate of $86.7 \%$.

\subsection{Reliability Test}

To make sure that items on the instrument are measuring the same thing. Internalconsistency reliability was measured using Cronbach's alpha coefficient. The internalconsistency of all items of the employees' questionnaire scale is verified with alpha coefficient of 0.969. In addition, constructs Cronbach's alpha is ranging from a minimum value of 0.813 and a maximum value of 0.938 which indicates high internal consistency. In addition, the internal-consistency of all items of the customers' questionnaire scale is verified with alpha coefficient of 0.883 . In addition, Constructs Cronbach's alpha is ranging from a minimum value of 0.738 and a maximum value of 0.860 which indicates high internal consistency.

\subsection{Factor Analysis (FA)}

FA allows testing hypothesis that a relationship between the observed variables and their underlying latent constructs exists (Shaqrah, 2008). FA was conducted on the conceptual research model (figure 2); according to which there are 39 items (i.e. observed variables) supposed to be saturated on 9 factors (i.e. latent variables).

Table (1) summarises FA results: it shows scale items and their corresponding factor loading, the highlighted items are items with factor loading less than 0.40, and they were removed from the scale before conducting any further analysis. In addition, both explanation items and prompt handling items are loaded on the same factor (factor 3) and thus they were integrated into one construct.

International Journal of Management and Applied Research, 2015, Vol. 2, No. 1 
Table 1: Factor Loading for Scale Items

\begin{tabular}{|c|c|c|c|c|}
\hline Factor & Construct & Item & $\begin{array}{l}\text { spss } \\
\text { Code }\end{array}$ & $\begin{array}{c}\text { facto } \\
\mathbf{r} \\
\text { loadi } \\
\text { ng }\end{array}$ \\
\hline \multirow{4}{*}{$\begin{array}{l}\text { Factor } \\
8\end{array}$} & \multirow{4}{*}{$\begin{array}{c}\text { 1. CK } \\
\text { Capture }\end{array}$} & 1. ENR obtains customer information & Cap1 & 0.637 \\
\hline & & $\begin{array}{l}\text { 2. ENR is continuously doing a customer satisfaction } \\
\text { studies }\end{array}$ & Cap2 & 0.678 \\
\hline & & $\begin{array}{l}\text { 3. ENR encourages ongoing two-way } \\
\text { communication with key customers }\end{array}$ & Cap3 & 0.371 \\
\hline & & $\begin{array}{l}\text { 4. ENR gathers sufficient knowledge about } \\
\text { customer's preferences }\end{array}$ & Cap4 & 0.196 \\
\hline \multirow{5}{*}{$\begin{array}{l}\text { Factor } \\
4\end{array}$} & \multirow{5}{*}{$\begin{array}{l}\text { 2. CK } \\
\text { Sharing }\end{array}$} & $\begin{array}{l}\text { 5. ENR has processes for distributing knowledge } \\
\text { throughout the organization }\end{array}$ & $\begin{array}{c}\text { Shar } \\
1\end{array}$ & 0.705 \\
\hline & & $\begin{array}{l}\text { 6. Needed information to any employee is available } \\
\text { to him }\end{array}$ & $\begin{array}{c}\text { Shar } \\
2\end{array}$ & 0.668 \\
\hline & & $\begin{array}{l}\text { 7. Top management motivates employees to share } \\
\text { their knowledge }\end{array}$ & $\begin{array}{c}\text { Shar } \\
3\end{array}$ & 0.481 \\
\hline & & $\begin{array}{l}\text { 8. Individualized information about each customer is } \\
\text { available at all contact points }\end{array}$ & $\begin{array}{c}\text { Shar } \\
4\end{array}$ & 0.265 \\
\hline & & $\begin{array}{l}\text { 9. ENR transfer knowledge about new services to its } \\
\text { customers }\end{array}$ & $\begin{array}{c}\text { Shar } \\
5\end{array}$ & 0.184 \\
\hline \multirow{3}{*}{$\begin{array}{l}\text { Factor } \\
\quad 6\end{array}$} & \multirow{3}{*}{$\begin{array}{l}\text { 3. CK } \\
\text { Acquisition }\end{array}$} & $\begin{array}{l}\text { 10.Employees fully understand CK necessary to carry } \\
\text { out their tasks }\end{array}$ & Acq1 & 0.634 \\
\hline & & $\begin{array}{l}\text { 11.ENR has processes for generating new knowledge } \\
\text { from CK }\end{array}$ & Acq2 & 0.401 \\
\hline & & $\begin{array}{l}\text { 12.ENR gets most of its valuable technical know- } \\
\text { how related to supplying its services from } \\
\text { customers }\end{array}$ & Acq3 & 0.287 \\
\hline \multirow{10}{*}{$\begin{array}{l}\text { Factor } \\
1\end{array}$} & \multirow{10}{*}{$\begin{array}{l}\text { 4. CK } \\
\text { Application }\end{array}$} & $\begin{array}{l}\text { 13.ENR has processes for learning from past } \\
\text { mistakes }\end{array}$ & Apl1 & 0.564 \\
\hline & & $\begin{array}{l}\text { 14.ENR has processes for using knowledge to solve } \\
\text { new problems }\end{array}$ & Apl2 & 0.728 \\
\hline & & $\begin{array}{l}\text { 15.ENR can take decisions rapidly thanks to } \\
\text { availability of knowledge about customers }\end{array}$ & Apl3 & 0.771 \\
\hline & & 16.ENR uses customers' ideas to meet their needs & Apl4 & 0.779 \\
\hline & & 17.CK helps ENR to make better decisions & Ap15 & 0.772 \\
\hline & & 18.ENR uses CK obtained to improve its services & Apl6 & 0.785 \\
\hline & & 19.ENR uses CK obtained to develop new services & Ap17 & 0.779 \\
\hline & & $\begin{array}{l}\text { 20.ENR has improved its ability to innovate new } \\
\text { services }\end{array}$ & Apl8 & 0.630 \\
\hline & & 21.ENR provides new services to its customers & Ap19 & 0.584 \\
\hline & & $\begin{array}{l}\text { 22. ENR provides significantly improved services to } \\
\text { its customers }\end{array}$ & $\begin{array}{c}\text { Apl1 } \\
0\end{array}$ & 0.551 \\
\hline
\end{tabular}


The Role of Customer Knowledge Management Process in Service Recovery Performance: An Applied Study to the Egyptian National Railways

\begin{tabular}{|c|c|c|c|c|}
\hline \multirow{3}{*}{$\begin{array}{c}\text { Factor } \\
7\end{array}$} & \multirow{3}{*}{$\begin{array}{l}\text { 5. Making } \\
\text { an apology }\end{array}$} & $\begin{array}{l}\text { 23.Employee apologized to customer for service } \\
\text { failure situation }\end{array}$ & $\begin{array}{c}\text { Apol } \\
1\end{array}$ & 0.775 \\
\hline & & $\begin{array}{l}\text { 24. The ENR apologized to customer for the } \\
\text { inconvenience caused by the service failure }\end{array}$ & $\begin{array}{l}\text { Apol } \\
2\end{array}$ & 0.735 \\
\hline & & 25.Employee expressed regret for the service failure & $\begin{array}{c}\text { Apol } \\
3\end{array}$ & 0.355 \\
\hline \multirow{4}{*}{$\begin{array}{l}\text { Factor } \\
5\end{array}$} & \multirow{4}{*}{$\begin{array}{l}\text { 6. Problem } \\
\text { solving }\end{array}$} & 26.Employee knew the solutions to the problem & Sol1 & 0.437 \\
\hline & & $\begin{array}{l}\text { 27. Employees did everything possible to solve } \\
\text { customer problem }\end{array}$ & Sol2 & 0.094 \\
\hline & & $\begin{array}{l}\text { 28. Employees have enough authority to solve the } \\
\text { problem }\end{array}$ & Sol3 & 0.687 \\
\hline & & $\begin{array}{l}\text { 29.In resolving the problem, ENR gave customers } \\
\text { what they needed }\end{array}$ & Sol4 & 0.535 \\
\hline \multirow{4}{*}{$\begin{array}{l}\text { Factor } \\
2\end{array}$} & \multirow{4}{*}{$\begin{array}{l}\text { 7. Being } \\
\text { courteous }\end{array}$} & $\begin{array}{l}\text { 30.Employee was treating customers in a friendly } \\
\text { way }\end{array}$ & $\begin{array}{c}\text { Cour } \\
1\end{array}$ & 0.863 \\
\hline & & $\begin{array}{l}\text { 31.Employee was polite when dealing with } \\
\text { complaining customer }\end{array}$ & $\begin{array}{c}\text { Cour } \\
2\end{array}$ & 0.887 \\
\hline & & 32.Employee showed respect to customer & $\begin{array}{c}\text { Cour } \\
3\end{array}$ & 0.832 \\
\hline & & $\begin{array}{l}\text { 33. Employee was patient when dealing with } \\
\text { complaining customer }\end{array}$ & $\begin{array}{c}\text { Cour } \\
4\end{array}$ & 0.742 \\
\hline \multirow{3}{*}{$\begin{array}{c}\text { Factor } \\
\mathbf{3}\end{array}$} & \multirow{3}{*}{$\begin{array}{l}\text { 8. Providing } \\
\text { an } \\
\text { explanation }\end{array}$} & $\begin{array}{l}\text { 34.Employee explained what factors might have } \\
\text { caused the problem }\end{array}$ & Exp1 & 0.684 \\
\hline & & 35.Employee explained what might have gone wrong & Exp2 & 0.730 \\
\hline & & $\begin{array}{l}\text { 36. Employee gave customer a reasonable explanation } \\
\text { for service failure }\end{array}$ & Exp3 & 0.684 \\
\hline \multirow{3}{*}{$\begin{array}{c}\text { Factor } \\
\mathbf{3}\end{array}$} & \multirow{3}{*}{$\begin{array}{l}\text { 9. Prompt } \\
\text { handling }\end{array}$} & 37.Employee reacted promptly to customer inquiries & $\begin{array}{c}\text { Hand } \\
1\end{array}$ & 0.576 \\
\hline & & $\begin{array}{l}\text { 38.Employee responded to customer complaints } \\
\text { promptly }\end{array}$ & $\begin{array}{c}\text { Hand } \\
2\end{array}$ & 0.589 \\
\hline & & $\begin{array}{l}\text { 39.The complaint handling process in the Egyptian } \\
\text { National Railways was quick }\end{array}$ & $\begin{array}{c}\text { Hand } \\
3\end{array}$ & 0.566 \\
\hline
\end{tabular}

\subsection{Modified Research Model}

FA results indicated the necessity of deleting 7 problematic items (number 3, 4, 8, 9, 12 , 25 , and 27) which have factor loading less than 0.40 . Therefore, the modified scale would include 32 items. Moreover, both of providing an explanation items and prompt handling items has been integrated into a new construct called timely feedback as shown in figure (3).

The modified 32-item scale was subjected to reliability and validity tests. Results confirm internal-consistency reliability of the scale items. FA results support the modified model as all 32 items have factor loading greater than 0.40 and each of them is saturated on its proposed construct.

International Journal of Management and Applied Research, 2015, Vol. 2, No. 1 
Figure 3: Modified Research Model

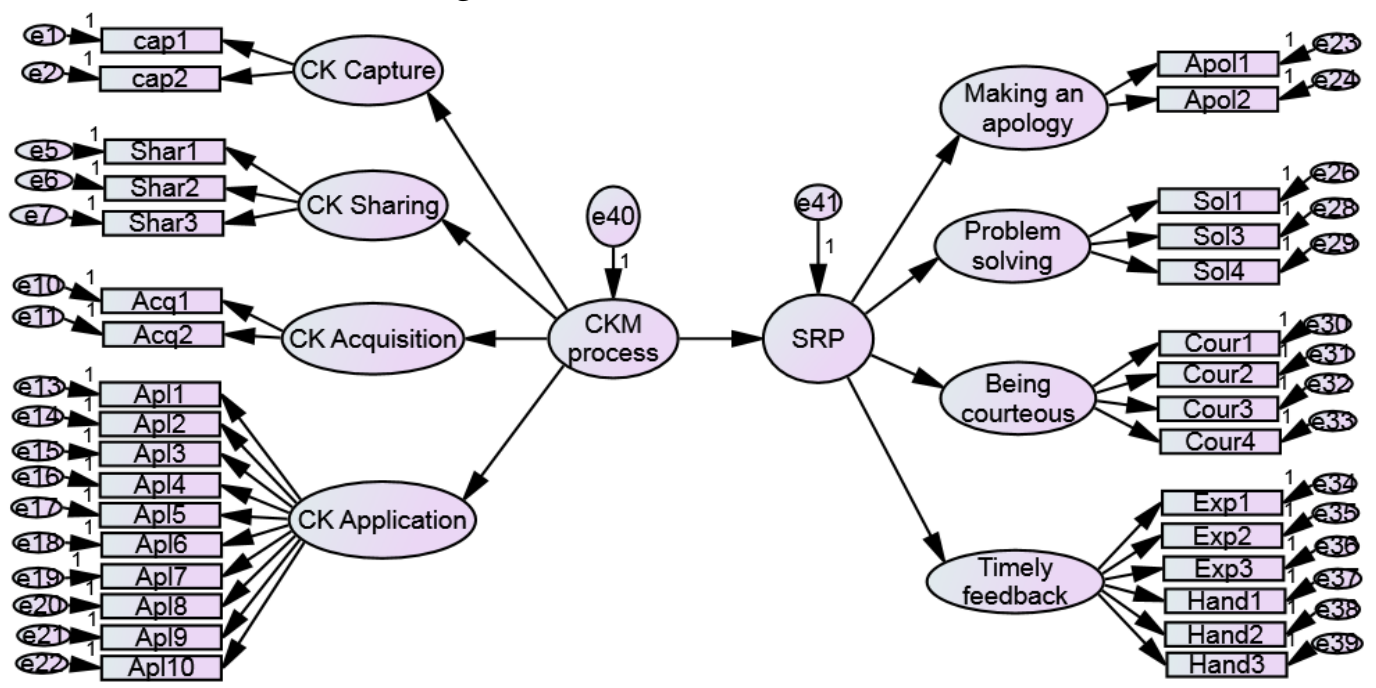

\section{Results and Discussion}

Simple linear regression would be used to verify whether the process of CKM has a positive impact on SRP. The results of simple linear regression, displayed in Table 2, indicate that CKM process is positively and significantly affects SRP.

Table 2: Simple Linear Regression Results Illustrating CKM Process Impact on SRP

\begin{tabular}{ccccccc}
\hline $\begin{array}{c}\text { Independent } \\
\text { Variable }\end{array}$ & $\begin{array}{c}\text { Dependent } \\
\text { Variable }\end{array}$ & $\boldsymbol{\beta}$ & $\mathbf{B}$ & $\begin{array}{c}\text { Adjusted } \\
\mathbf{R}^{\mathbf{2}}\end{array}$ & $\mathbf{F}$ & $\begin{array}{c}\text { Sig. } \\
(\alpha=0.05)\end{array}$ \\
\hline $\begin{array}{c}\text { CKM } \\
\text { process }\end{array}$ & SRP & 0.632 & 0.626 & 0.396 & 133.480 & 0.000
\end{tabular}

Table (2) illustrates that: Standardized regression coefficient ( $\beta$ ) equal 0.632 indicating that there is a positive relationship between CKM process and SRP. Unstandardized regression coefficient (B) equal 0.626 indicating that for every one unit increase in CKM process, there is a predicted increase in SRP by about 63\%; so that CKM process has an impact on SRP. The coefficient of determination $\left(\mathrm{R}^{2}\right)$ value is 0.396 reflecting that, CKM process explains about $40 \%$ of the total change in SRP; whereas, the residual $60 \%$ is due to other factors not included in this research. F value is 133.480 with significance equal 0.000 (which is less than 0.05); meaning that, CKM process significantly affects SRP. Therefore, CKM process has a positive and significant impact on SRP; indicating that, when the ENR succeed in managing its customer knowledge effectively, its performance in implementing a successful service recovery strategy would improve. This result confirms the study of Boateng and Agyemang (2015) which concluded that $\mathrm{CK}$ sharing and application have a positive influence to service recovery performance.

International Journal of Management and Applied Research, 2015, Vol. 2, No. 1 
The current research tries to identify whether each stage of CKM process (i.e. CK capture, CK sharing, CK acquisition, and CK application) have a significant impact on SRP, using the stepwise regression analysis. Table 3 summarises the results of the stepwise regression analysis.

Table 3: Stepwise Regression Results Illustrating CKM Stages Impact on SRP

\begin{tabular}{clcccccc}
\hline $\begin{array}{c}\text { Dependent } \\
\text { Variable }\end{array}$ & $\begin{array}{c}\text { Independent } \\
\text { Variables }\end{array}$ & $\boldsymbol{\beta}$ & $\mathbf{B}$ & $\mathbf{T}$ & $\begin{array}{c}\text { Sig. } \\
(\alpha= \\
0.05)\end{array}$ & $\begin{array}{c}\text { Adjusted } \\
\mathbf{R}^{\mathbf{2}}\end{array}$ & $\mathbf{F}$ \\
\hline \multirow{3}{*}{ SRP } & CK application & 0.338 & 0.324 & 4.736 & 0.000 & & 58.219 \\
& CK capture & 0.244 & 0.173 & 3.916 & 0.000 & 0.459 & (Sig.= \\
& CK acquisition & 0.239 & 0.202 & 3.628 & 0.000 & & $0.000)$
\end{tabular}

Table 3 illustrates that: The coefficient of determination $\left(\mathrm{R}^{2}\right)$ for the whole model equals 0.459 , reflecting that the combination $\mathrm{CK}$ application, $\mathrm{CK}$ capture, and $\mathrm{CK}$ acquisition explains about $46 \%$ of the total change in SRP; whereas the residual $54 \%$ is due to other factors. $\mathrm{F}$ value is 58.219 with significance equal 0.000 (which is less than 0.05); meaning that, the combination of $\mathrm{CK}$ application, CK capture, and CK acquisition affects SRP significantly. There are positive relationships between the SRP and each of CK application, CK capture, and CK acquisition, where $\beta$ values are $0.338,0.244$, and 0.239 respectively. $\mathrm{CK}$ application has the greatest impact on SRP with B value equal 0.324 , followed by $C K$ acquisition with $B$ value equal 0.202 ; while $C K$ capture has the lowest impact on SRP with B value equal 0.173. All CKM stages - except CK sharinghave significant effects on SRP; meaning that the ENR's performance on service recovery is affected by its capture, acquisition, and application of CK. While, there is no significant impact of CK sharing on the ENR's performance on service recovery; and that may result from, each employee has the sufficient customer knowledge that enables him from carrying out his tasks; so that, his performance doesn't affected by the sharing of knowledge with other organisational members. Based on the previous result, organisations need to pay more attention to $\mathrm{CK}$ application, $\mathrm{CK}$ acquisition, and $\mathrm{CK}$ capture respectively; in order to improve their service recovery performance.

These results would refer to, the organisation (i.e. the ENR) need to emphasize more on its customer knowledge management process while developing and applying its service recovery strategy; through focusing more on capturing, acquiring, and applying its customer knowledge regarding the service failure and their expectations about the recovery performance.

Mann-Whitney "U" Test was used to investigate whether there are differences in opinions of customers and employees regarding their evaluation to service recovery performance. The results of Mann-Whitney "U" Test, displayed in Table 4, indicate that there are significant differences between employees' opinions and customers' opinions regarding the ENR's service recovery performance. 
Table 4: Mann-Whitney "U" Test Results

\begin{tabular}{cccccc}
\hline Variable & Sample & Mean Rank & $\mathbf{U}$ & $\mathbf{Z}$ & $\begin{array}{c}\text { Sig. } \\
(\alpha=0.05)\end{array}$ \\
\hline SRP & Employees & 382.95 & \multirow{2}{*}{9.958} & 14.007 & 0.000
\end{tabular}

Table 4 illustrates that: $\mathrm{Z}$ value equals 14.007 with significance equal 0.000 , meaning that there are significant differences between employees' opinions and customers' opinions regarding the ENR's service recovery performance. Employees' mean rank is approximately 383 whereas the customers' mean rank is nearly 196, indicating that employees evaluate the ENR's service recovery performance more positively than customers do. This result would be explained as the ENR's employees overestimate their performance on service recovery as a result of their fear from responsibility and accountability.

\section{Conclusion}

The results of current research demonstrated that CKM process has a positive and significant impact on SRP. The results suggest that when an organisation succeeds in managing its customer knowledge effectively, it is highly likely that its SRP would improve accordingly. This finding is consistent with the work of (Boateng and Agyemang, 2015: 124) which found that customer knowledge sharing and application significantly affect SRP. In other words, there is a need for organisations capture and share customer knowledge effectively in order to ensure customer satisfaction through service recovery (Guo and Niu, 2007).

The results also indicated that CKM process has a positive and significant effect on each dimension of SRP. Therefore, when an organisation executes the CKM process effectively that would be reflected on: a) its ability to provide its customers with the appropriate and desired apology for any service failure occurrence; b) its success in solving any problem could face its customers; c) its employees' success in dealing courteously with customers; and d) its ability to provide its customers with a reasonable and continuously updated explanation for any service failure and what is being done to solve it.

CK application stage has the greatest impact - among all other CKM process stages on SRP and all of its dimensions, i.e. making an apology, problem solving, being courteous, and timely feedback. CK sharing stage doesn't have a significant impact on SRP, making an apology, being courteous and timely feedback. Whereas; CK capture stage doesn't have a significant impact on being courteous. While, CK acquisition stage doesn't have a significant impact on problem solving dimension. Finally, one of the important results of the current research is that employees' evaluate the service recovery performance more positively than customers' evaluation. This result may indicate that employees overestimate their performance on service recovery.

International Journal of Management and Applied Research, 2015, Vol. 2, No. 1 
The empirical results indicated that organisations need to manage customer knowledge more efficiently in order to improve their service recovery performance. The results also demonstrated that employees evaluate their performance regarding the service recovery more positively than what customers do. In short, this research has demonstrated the value of managing customer knowledge effectively in order to achieve a better performance on service recovery.

The results of this study provide important managerial implications, particularly for passengers transport operators that seek to improve their customer services. First, transport operators such as ENR could manage its customer knowledge effectively in order to identify customers' needs and expectations toward ENR regarding any possible service failure. This could be done by collecting customers' evaluations and feedbacks regarding current service, what they expect the ENR do in response to any possible service failure, and their suggestions to improve the ENR's services. ENR could also collect data about customers' purchasing activities, i.e. how customers identify services, how they evaluate them, and how they choose the desired service, their financial capabilities, and their information needs.

Second, ENR could inform customers regarding changes in service delivery in a timely manner. This may include: a) changes in the trains' timetables and the reasons for this change, b) changes in the service providing procedures, c) new services or any improvements of the current services, d) the reasons for any service failure occurrence, and potentially e) formal apology or statement maintaining ENR's responsibility and regret when it fails in providing any service.

Third, ENR could disseminate and share customer knowledge among its employees and this can be done by: enabling employees from having access to customer information; encouraging employees to share their knowledge or observation about the customers; and promoting open discussions between employees regarding customers' needs, preferences, feedbacks, suggestions, or problems.

And last but not least, ENR could make use of customers' suggestions and expectations in order to improve current services, which include providing additional services, mitigating potential operational risks, avoiding service failure and/or recovering from service failure, as well as establishing service recovery strategy.

The current research sought to measure the impact of CKM process on SRP all from employees' perspective, and to compare the evaluation of the ENR's employees and customers regarding the SRP. However, the results indicated that there is a significant difference between perception of employees and customers regarding service recovery performance, suggesting a mismatch between customer expectation and employee performance. Future research could examine the customers' perspective in-depth to gather more integrated results.

It would be beneficial to study the impact of managing customer knowledge on customers' satisfaction with service recovery. The customer perspective of service recovery would offer an insight of perceived customer satisfaction especially in terms of

International Journal of Management and Applied Research, 2015, Vol. 2, No. 1 
willingness to accept solution to service failure. Furthermore, the employees' views of service recovery would provide additional insight on the impact of customer knowledge management process to proactive (preventive) service recovery. Accordingly, it would be fruitful to integrate CKM process with the other factors that could affect SRP -- such as employee empowerment -- and investigating their effects on service recovery performance, from employees' perspective.

\section{References}

1. Akbar, S., Som, A., Wadood, F. and Alzaidiyeen, N. (2010), "Revitalization of Service Quality to Gain Customer Satisfaction and Loyalty", International Journal of Business and Management, Vol.5, No.6, pp.113-122. https://doi.org/10.5539/ijbm.v5n6p113

2. Belkahla, W. and Triki, A. (2011), "Customer Knowledge Enabled Innovation Capability: Proposing a Measurement Scale", Journal of Knowledge

Management, Vol. 15, No. 4, pp. 648-674. https://doi.org/10.1108/13673271111152009

3. Bitner, M., Booms, B. and Mohr, L. (1994), "Critical Service Encounter: The Employee's Viewpoint", Journal of Marketing, Vol. 58, No.4, pp. 95-106. https://doi.org/10.2307/1251871

4. Boateng, H. and Agyemang, F. G. (2015), "The effects of knowledge sharing and knowledge application on service recovery performance", Business

Information Review, Vol. 32, No. 2, pp. 119-126.

https://doi.org/10.1177/0266382115587852

5. Boshoff, C. (1999), "RECOVSAT: An Instrument to Measure Satisfaction with Transaction-Specific Service Recovery", Journal of Service Research, Vol.1, No.3, pp. 236-249. https://doi.org/10.1177/109467059913005

6. Boshoff, C. and Allen, J. (2000), "The Influence of Selected Antecedents on Frontline Staff's Perceptions on Service Recovery Performance", International Journal of Service Industry Management, Vol.11, No. 1, pp. 63-90. https://doi.org/10.1108/09564230010310295

7. Boshoff, C. (2005), "A re-assessment and refinement of RECOVSAT: An instrument to measure satisfaction with transaction-specific service recovery", Managing Service Quality: An International Journal, Vol. 15, No. 5, pp.410 425. https://doi.org/10.1108/09604520510617275

8. Casidy, R. and Shin, H. (2015), "The effects of harm directions and service recovery strategies on customer forgiveness and negative word-of-mouth intentions", Journal of Retailing and Consumer Services, Vol. 27, pp. 103-112. https://doi.org/10.1016/j.jretconser.2015.07.012

International Journal of Management and Applied Research, 2015, Vol. 2, No. 1 
9. Chaharsoughi, M. (2008), "Prioritizing of Airline Service Recovery Solutions by Service Problem Deployment Technique with a Case Study in Iran-Air", M. Sc. Thesis, Lulea University of Technology.

10. Chen, T. and Huang, H. (2011), "An Integrated CKVC Model to Building Customer Knowledge Management Synergy and Impact on Business Performance", International Conference on Economics, Trade and Development, IPEDR, Singapore, Vol.7, pp. 78 - 82.

11. Daghfous, A., Campa, F. and Hamade, A. (2008), "Customer Development: A Knowledge Management Perspective and a Case Illustration in E-Government", European and Mediterranean Conference on Information Systems, Al Bustan Rotana Hotel, Dubai.

12. Dalkir, K. (2005), Knowledge Management in Theory and Practice, Boston: Elsevier, Butterworth-Heinemann.

13. El-Helaly, N. (2013), "The Impact of Customer Knowledge Management Process on Service Recovery: Applied on the Egyptian National Railways", M. Sc. Thesis, Faculty of Commerce, Mansoura University, Egypt.

14. El-Helaly, N., Ebeid, A., and El-Menbawey, A. (2013), "The Impact of Customer Knowledge Management Process on Service Recovery Performance", Proceedings of the 5th European Conference on Intellectual Capital (ECIC) Volume Two, Spain, April 11-12, 2013.

15. Garcia-Murillo, M. and Annabi, H. (2002), "Customer Knowledge Management", Journal of the Operational Research Society, Vol. 53, No. 8, pp. 875-884. https://doi.org/10.1057/palgrave.jors.2601365

16. Gu, B. and Ye, Q. (2010), "The Impact of Online Service Recovery on Customer Satisfaction: Empirical Evidences from Service Operations in China", McCombs Research Paper Series, No. IROM-01-10.

17. Gustafsson, A. (2009), "Customer Satisfaction with Service Recovery", Journal of Business Research, Vol. 62, No. 11, pp. 1220-1222.

https://doi.org/10.1016/j.jbusres.2008.11.001

18. Joireman, J.; Grégoire, Y.; Devezer, B. and Tripp, T. (2013), "When do customers offer firms a "second chance" following a double deviation? The impact of inferred firm motives on customer revenge and reconciliation", Journal of Retailing, Vol. 89, No. 3, pp. 315-337. https://doi.org/10.1016/j.jretai.2013.03.002.

19. Keaveney, S.M. (1995), "Customer switching behaviour in services industries: an exploratory study", Journal of Marketing, Vol. 59, No. 2, pp. 71-82.

20. Liao, H. (2007), "Do It Right This Time: The Role of Employee Service Recovery Performance in Customer-Perceived Justice and Customer Loyalty

International Journal of Management and Applied Research, 2015, Vol. 2, No. 1 
after Service Failures", Journal of Applied Psychology, Vol. 92, No.2, pp. 475489. https://doi.org/10.1037/0021-9010.92.2.475

21. Najjar, M., Smithy, A. and Kettingerz, W. (2010), "Stuff Happens: A Theoretical Framework for Internal IS Service Recovery", the 16th Americas Conference on Information Systems, Lima- Peru, August 12-15, 2010.

22. Parirokh, M., Daneshgar, F. and Fattahi, R. (2009), "A Theoretical Framework for Development of a Customer Knowledge Management System for Academic Libraries", the 75th IFLA General Conference and Council, Milan-Italy, August 23-27, 2009.

23. Patterson, P., Cowley, E. and Prasongsukarn, K. (2006), "Service Failure Recovery: The Moderating Impact of Individual-Level Cultural Value Orientation on Perceptions of Justice", International Journal of Research in Marketing, Vol. 23, No.3, pp. 263-277. https://doi.org/10.1016/j.ijresmar.2006.02.004

24. Río-Lanza, A., Vázquez-Casielles, R.and Díaz-Martín, M. (2009), "Satisfaction with Service Recovery: Perceived Justice and Emotional Responses", Journal of Business Research, Vol. 62, No. 8, pp. 775-781. https://doi.org/10.1016/j.jbusres.2008.09.015

25. Rod, M., Ashill, N. and Carruthers, J. (2008), "The Relationship between Job Demand Stressors, Service Recovery Performance and Job Outcomes in a StateOwned Enterprise", Journal of Retailing and Consumer Services, Vol. 15, No.1, pp. 22-31. https://doi.org/10.1016/j.jretconser.2007.02.002

26. Roy, T. and Stavropoulos, V. (2007), Customer Knowledge Management in the E-business Environment: Cases from Swedish Banks, M. Sc. Thesis, Lulea University of Technology.

27. Salojarvi, H. (2009), "Intra-Organisational Determinants of Customer Knowledge Acquisition in Key Account Management", Anzmac Conference, Melbourne-Australia, November 30 - December 2, 2009.

28. Salomann, H., Dous, M., Kolbe, L. and Brenner, W. (2005), "Rejuvenating Customer Management: How to Make Knowledge For, From and About Customers Work", European Management Journal, Vol. 23, No. 4, pp. 392-403. https://doi.org/10.1016/j.emj.2005.06.009

29. Sofianti, T., Suryadi, K., Govindaraju, R. and Prihartono, B. (2009), "Customer Knowledge Management in New Product Development", Asia Pacific Industrial Engineering \& Management Systems Conference, Kitakyushu-Japan, Dec. 1416, 2009.

30. Su, C., Chen, Y. and Sha, D. (2006), "Linking Innovative Product Development with Customer Knowledge: A Data-Mining Approach", Technovation, Vol. 26, No. 7, pp. 784-795. https://doi.org/10.1016/j.technovation.2005.05.005

International Journal of Management and Applied Research, 2015, Vol. 2, No. 1 
31. Tax, S. and Brown, S. (1998), "Recovering and Learning from Service Failure", Sloan Management Review, Vol. 40, No.1, 75-88.

32. Vaerenbergh, Y., Vermeir, I. and Lariviere, B. (2010), "Why Do Process Recovery Communications Work? Investigating the Mediating Role of Stability Attributions and Perceived Relationship Investment", The 11th International Research Seminar in Service Management, La Londe, les Maurres- France, May 25- 28, 2010.

33. Wang, Y., Wu, S., Lin, H. and Wang, Y. (2011), "The Relationship of Service Failure Severity, Service Recovery Justice and Perceived Switching Costs with Customer Loyalty in The Context of E-Tailing", International Journal of Information Management, Vol. 31, No. 4, pp. 350-359. https://doi.org/10.1016/j.ijinfomgt.2010.09.001

34. Williams, D. (2014), Connected CRM: Implementing a Data-Driven, CustomerCentric Business Strategy, New Jersey: John Wiley \& Sons.

35. Wu, J.; Guo, B. and Shi, Y. (2013), "Customer knowledge management and ITenabled business model innovation: A conceptual framework and a case study from China", European Management Journal, Vol. 31, No. 4, pp. 359-372, https://doi.org/10.1016/j.emj.2013.02.001. 